
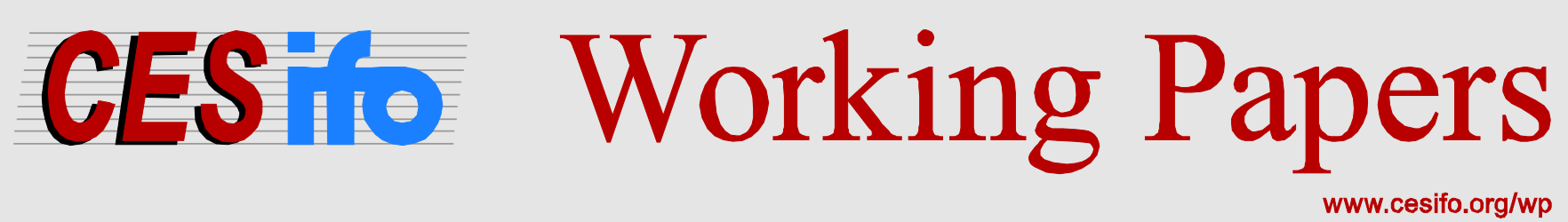

\title{
Employee Spinouts, Social Networks, and Family Firms
}

\author{
James E. Rauch
}

CESIFO WORKING PAPER NO. 4539

CATEGORY 11: INDUSTRIAL ORGANISATION

DECEMBER 2013
An electronic version of the paper may be downloaded
- from the SSRN website: Www.SSRN.com
- from the RePEc website: Www.RePEc.org
- from the CESifo website: www.CESifo-group.org/wp




\title{
Employee Spinouts, Social Networks, and Family Firms
}

\begin{abstract}
Recently collected data show that, within any manufacturing industry, vertically integrated firms tend to have larger, higher productivity plants, account for the bulk of sales, and also sell externally most of the inputs they produce. In a weak contracting environment characteristic of developing countries, vertically integrated firms are vulnerable to employee "spinouts": managers of input divisions can start their own firms, making customized inputs formerly provided internally subject to hold-up and capturing the profits formerly made from external sales of generic inputs. This vulnerability is shown to lead to inefficiently low entry. Vertically integrated firms can fight back by hiring managers for their input divisions who are members of networks that informally sanction hold-ups or children who keep profits "in the family" even if they spin out. This is shown to predict the association of co-ethnic networks with high rates of entrepreneurship and the prominence of family-owned business groups in developing country manufacturing.
\end{abstract}

JEL-Code: L140, L220, L260.

Keywords: employee spinouts, social networks, family firms, vertical disintegration, entrepreneurship, business groups.

James E. Rauch

Department of Economics

University of California, San Diego

9500 Gilman Drive

USA - 92093-0508 La Jolla CA

jrauch@ucsd.edu

December 2013

I thank Joel Watson for his many helpful comments and suggestions. I also thank participants in seminars at the International Monetary Fund, the National Bureau of Economic Research Entrepreneurship Working Group, and the University of California, San Diego. I am responsible for any errors. 


\section{Introduction}

Data recently collected by Atalay, Hortaçsu and Syverson (2013) show that, within narrowly-defined manufacturing industries, vertically integrated firms are larger (and have larger plants) and have higher productivity. These data, collected for the United States for the period 1977-97, also show that vertically integrated firms account for about $70 \%$ of the value of manufacturing output. ${ }^{1}$ Comparably detailed studies are not available for developing countries, but we can expect the need for larger, more productive firms to produce their own inputs to be even stronger in these countries. Tybout (2000, p. 14) reports: "The menu of domestically produced intermediate inputs and capital equipment is also often limited in developing countries. Thus producers who might easily have acquired specialized inputs if they were operating in an OECD country must either make do with imperfect substitutes or import the needed inputs at extra expense."

An employee supplying a material or service input inside a vertically integrated firm may become an independent producer of that input, typically then entering a subcontracting relationship with his former employer. Shieh (1992) devotes an entire chapter of his study of subcontracting in Taiwanese manufacturing to "Spinning Off 'Bosses'." I call the firms founded by these employees "spinouts" (rather than the more generic "spinoffs") to emphasize the “externalization" of formerly internally supplied inputs. ${ }^{2}$

Entrepreneurs who found spinouts may work harder than they did for their former employers. Yet spinouts are a double-edged sword in a weak contracting environment. Well-

\footnotetext{
${ }^{1}$ This figure is from Table 1.B of an earlier draft of the Atalay, Hortaçsu and Syverson paper entitled "Vertical Integration and Production: Some Plant-Level Evidence."

${ }^{2}$ Employee spinoffs have long been recognized as an important source of new firm formation, but only recently have data become available that allow this importance to be quantified. Muendler, Rauch and Tocoian (2012) find that, depending on definition, employee spinoffs account for between one-sixth and one-third of new firm formation in Brazil during the period 1995-2001.
} 
known inefficiencies may arise in the now arm's-length customer-supplier relationship. A potentially more important problem is that a spinout deprives a vertically integrated firm of a significant revenue stream. As I describe in more detail in section 2, Atalay, Hortasçu and Syverson (2013) find that vertically integrated firms sell the bulk of their internally produced inputs externally. Former employers cannot force spinouts to compensate them for the profits lost from these external sales of inputs without effective non-compete enforcement and/or patent protection. In developing countries, the knowledge possessed by spinouts is probably not patentable, and enforcement of non-compete contracts is likely to be too slow, if it happens at all. Gilson (1999) states that in the United States the most often used way for a firm to use a noncompete clause in its contract with an employee is through a preliminary injunction. ${ }^{3}$ Otherwise the non-compete clause is ineffective because by the time it is enforced the damage to the employer's business has already been done. Fear of employee entrepreneurship is said to be especially pervasive in the Chinese context. Tong (2006, p. 14) writes, "There is fear that employees will learn too much about the business and gain the secrets of the business. Having done so, they will break away and start their own firms, taking away business and becoming a competitor."

I shall argue that these contractual difficulties discourage entry of vertically integrated firms. This is important since larger, more productive firms account for most exports (Melitz 2003) and are therefore crucial for the ability of developing countries to take advantage of the gains from trade (Rauch 2010). Moreover, since vertically integrated firms sell most of their intermediate output externally, fewer of them (and their spinouts) means fewer locally supplied

\footnotetext{
${ }^{3}$ In personal communication (2008), Lawrence Carnevale, a prominent New York attorney specializing in employment law, states, "Those prosecuting or defending non-compete actions may be called upon to argue the merits of such clauses in court within hours of the employee's notice." Even within the United States, however, enforcement of non-compete contracts is uneven (Malsberger 2006) and changes over time (Garmaise 2011).
} 
inputs, leading to a low local content of developing country exports and contributing to precisely the state of affairs regarding intermediates that Tybout described above.

Employers can mitigate the impact of these contractual problems by hiring managers of their input divisions who are members of networks that support efficient subcontracting relationships through informal punishment of opportunistic behavior, or children who keep profits "in the family" even if they spin out. Regarding the latter, Shieh (1992, p. 184) writes it is the middle-level or above managerial staffs who are more likely to open their own workshops. Hence a gap in promotion channel prevents line workers from setting up their own businesses, yet guarantees more opportunities for the managerial staffs of the inner circle of the boss.... Only the family members of the boss can be promoted to the key positions....the family-based enterprises, which are the majority of Taiwanese enterprises, reserve training opportunities for the family members of the boss, for they fear that non-family-member employees may quit someday and the investment in training would be in vain, not to mention the threat from the potential competitors cultivated by their own hands. Familism here is a condition for the relatives or in-circle members of the boss to spin-off, which may in turn reinforce familism.

The most readily identifiable networks are based on ethnicity. Studies of ethnic minority entrepreneurship consistently emphasize that these groups collectively sanction deviant behavior in business dealings (see Alesina and La Ferrara 2005 for references). ${ }^{4}$

The advantages of hiring members of social networks or children help to explain the prominence of ethnic minorities and family business groups in developing country economies. ${ }^{5}$ Our model is also consistent with more subtle findings regarding family firms. Bertrand et al. (2008, Table 8) find that the number of sons of the founder of a family business group in Thailand does not affect the number of firms in the group until after the founder has died. This

\footnotetext{
${ }^{4}$ Regarding ethnic Chinese networks, Chung and Hamilton (2001, p. 335) write, "everyone linked together through interpersonal networks observes the actions of everyone else, and thus everyone shares the same rules and, collectively or individually, can sanction those who do not live up to their obligations."

${ }^{5}$ For a discussion and numerous examples of "market-dominant" ethnic minorities, see Chua (1998). In their survey article, Khanna and Yafeh (2007, p. 332) state, "in virtually all emerging markets, group-affiliated firms tend to be relatively large and economically important." They also write (p. 352), "the vast majority of business groups began as family dominated corporations".
} 
could be because sons exert higher effort than non-family managers when monitored by the parent-founder, making spinouts less advantageous until after his death. At the same time, founding entrepreneurs may be willing to hire children who are not the best available employees in order to keep profits from any subsequent spinouts in the family. These offsetting influences on family firm profitability are consistent with the contradictory results in the literature. ${ }^{6}$

In the next section of this paper I construct an industry model in which larger firms producing higher quality goods are vertically integrated, yet sell most of their produced inputs externally. The main focus of the model is on negotiations between the founder of a vertically integrated firm and the manager of its input division. In section 3 I analyze the cases where that manager is a member of the founder's social network or his family. The concluding section discusses the implications of the model for policy and for understanding the role of family business groups in economic development.

\section{A model of vertical disintegration through employee spinouts}

An industry in a developing country can produce both low and high quality final goods using imported intermediates. Low quality final goods are homogeneous and are sold domestically. High quality final goods are differentiated and are sold abroad.

The economy in which this industry resides is populated by risk neutral old and young agents. A measure $N$ of old agents is available to establish and manage firms in this particular industry. I will follow Lucas (1978) and assume that a fixed distribution of managerial talent

\footnotetext{
${ }^{6}$ Claessens et al. (2002) and Cronqvist and Nilsson (2003) find that family firms are associated with lower stock market valuations and lower rates of return, whereas Anderson and Reeb (2003) and Khanna and Palepu (2000) find the opposite.
} 
$G: \mathbb{R}^{+} \rightarrow[0,1]$ exists in the population. This talent is only useful when managing firms that produce high quality final goods. ${ }^{7}$ It follows that it is irrelevant for young agents. Young agents can, however, be divided into skilled and unskilled. Among the skilled are a subset of measure greater than $N$ who have achieved the highest observable technical preparation for work in this industry; for example they have completed the requisite specialized education with the highest possible grades. These highly skilled young workers will be demanded by entrepreneurmanagers who want to produce high quality final goods in this industry; the remaining skilled young workers will supply labor to the rest of the economy. However, I will later want to consider the possibility that entrepreneurs who produce high quality final goods hire their children even if they are less technically proficient.

An old agent who enters high quality final goods production has a challenging task. He must develop an in-house design capability and customize one of the imported inputs in order to differentiate his product for foreign buyers and attract market share. This is an expensive process that requires hiring and training one of the highly skilled young workers described above, who will embody the in-house design capability and oversee production of the input. In order to defray these expenses, the firm also produces a generic version of the input which it sells in competition with imports.

I assume that the worker can choose the effort he exerts in management of the production of the generic input, but that no effort choice is possible in production of the customized input because it is too closely coordinated with production of the final good and therefore too closely supervised by the entrepreneur. I further assume that this worker can, at some cost, establish his

\footnotetext{
${ }^{7}$ We can think of managerial talent as sales ability that allows the firm to obtain a higher price for its differentiated product, but is useless for a firm that produces a homogenous good the price of which is determined in a perfectly competitive market. It would complicate but not qualitatively change the model if I instead assumed that managerial talent was also useful when managing firms that produce low quality final goods, provided that profits from high quality production increase more rapidly with managerial talent than do profits from low quality production.
} 
own firm to produce the customized and generic versions of the input. The worker's spinout implies the vertical disintegration of the original firm. In my model, then, firms vertically integrate because of the difficulties of contracting out the creation of a distinctive final good and customized input; they may vertically disintegrate due to problems with worker incentives described below. Intrafirm purchasing of creative or problem-solving tasks like input customization is consistent with the adaptive theory of the firm (Gibbons 2005, Forbes and Lederman 2009) and with the findings of Costinot, Oldenski and Rauch (2011) for U.S. multinationals.

The worker's effort decision is made in the context of the competition with imports of either the input division of the vertically integrated firm or the spinout firm. For simplicity, let all imported inputs be symmetric and produced abroad at constant marginal $\operatorname{cost} c^{*}$, and let $\tau>1$ be the number of units that need to be shipped if one unit is to arrive. I assume that the domestic constant marginal cost of production of a generic input $c$ remains within the open interval $\left(c^{*} / \tau, \tau c^{*}\right)$ regardless of the level of worker effort. Either the vertically integrated or the spinout firm then practices limit pricing as in Grossman and Helpman (1991), selling the input to other domestic final goods producers at the foreign (transportation inclusive) marginal cost. ${ }^{8}$ Unlike in Grossman and Helpman (1991), however, transportation costs allow the foreign producer to keep the domestic producer of the input out of its home market.

The profits of the input subsidiary are now given by

$$
\pi_{S}=\left[\tau c^{*}-c(e)\right] D\left(\tau c^{*}\right),
$$

where $e$ is worker effort and $D\left(\tau c^{*}\right)$ is the demand of domestic producers for the generic input at the price $\tau c^{*}$. (We can think of this demand as generated, for example, by a CES production

\footnotetext{
${ }^{8}$ Specifically, this corresponds to the "narrow gap" case in Grossman and Helpman (1991), where wages in developing country are not so much lower than wages in advanced country that the former can charge the full CES markup over marginal cost and still undercut the marginal cost of the latter.
} 
function for each domestic producer that is symmetric in all the generic inputs.) I assume that $c^{\prime}<0, c^{\prime \prime}>0, \lim _{e \rightarrow 0} c^{\prime}(e)=-\infty$, and $\lim _{e \rightarrow \infty} c^{\prime}(e)=0$. Note that profits of the input subsidiary depend on worker effort but not on managerial talent, and are similar in the latter respect to profits from sales of the low quality final good. The cost of effort to the worker and other determinants of his effort decision are specified below.

I now let $\pi_{H}(z, \mu)$ denote profits exclusive of fixed costs from sales of a high quality final good for a firm managed by an old agent with talent level $z$ that pays $\mu$ per unit for the customized input. I also let $F$ denote the fixed cost of establishing production of the customized input. Finally, I let $\pi_{L}$ denote profits from sales of a low quality final good for a firm managed by an old agent with any level of managerial talent. Assume that $\pi_{H}(z, \mu)$ is increasing in $z$ and decreasing in $\mu$. It is clear that the old agents with greatest managerial talent will select into production of high quality final goods, leading these firms to be larger and more productive.

It follows that the largest, most productive firms are vertically integrated, since producers of high quality final goods supply their customized inputs internally. Also consistent with Atalay, Hortaçsu and Syverson (2013), the ratios of internal to external sales or shipments of the input for the vertically integrated firms are small. ${ }^{9}$ In my model this occurs because the vertically integrated firms use only the customized input themselves while selling the generic version to all domestic producers that previously imported this intermediate. However, internal shipments of the input cannot be zero, which occurs for nearly half of the vertically integrated firms in the sample of Atalay et al. I conjecture that the zeros in their data occur because some firms produce the customized version of the input they developed in the same plant in which they produce the final good that uses it, while dedicating their separate plant to the generic version of

\footnotetext{
${ }^{9}$ Atalay, Hortaçsu and Syverson (2013) find that the median internal shipments share across upstream establishments in vertical production chains is 0.4 percent.
} 
the input, so that no internal shipments of the input are recorded. This is consistent with the idea that production of the customized version of the input requires closer supervision, as I assumed above.

To determine whether the high quality final goods producer remains vertically integrated or experiences an employee spinout, I specify the timing of the interaction between the old agent (entrepreneur) and the young agent (worker) as follows:

(i) The entrepreneur and the worker are matched randomly, and the entrepreneur hires and trains the worker. The worker is liquidity-constrained, and therefore cannot make a transfer to the entrepreneur to cover any future losses the latter might suffer if the worker spins out. Inability to borrow against one's human capital is realistic for young agents in the developing country context and can be thought of as part of the weak contracting environment. ${ }^{10}$ I maintain the assumption that the worker is liquidity-constrained throughout the analysis.

(ii) The worker discovers his fixed cost, measured in terms of his own time, to establish his own business. Specifically, the worker draws the cost $x$ from a fixed distribution $Y$ with support $[0, \bar{x}]$. The entrepreneur as well as the worker observes $x$.

(iii) The entrepreneur and the worker decide whether to separate. If they stay together, the entrepreneur makes a transfer to the worker. I label the continuation (a) if they stay together and (b) if they separate.

(iv.a) The worker produces the customized input at constant marginal cost $\bar{\mu}$ and the entrepreneur produces the final good, obtaining profit $\pi_{H}(z, \bar{\mu})$. The worker also produces the generic input at marginal cost $c(e)$. Neither the amount of effort supplied by the worker nor the

\footnotetext{
${ }^{10}$ Since the entrepreneur incurs the fixed cost $F$, he must not be liquidity constrained. This could be because lenders make loans to businesses but not pure human capital loans, or because having wealth adequate to finance the fixed cost of starting high quality final goods production is a condition for being considered part of the pool of older agents who are potential entrepreneurs for this industry.
} 
marginal cost is verifiable outside the firm. Moreover, the marginal cost cannot be inferred from the price the firm charges for the generic input since this is still optimally chosen to equal $\tau c^{*}$. Finally, due to vertical integration the profit earned from selling the generic input is mixed together with the profit earned from selling the final good, so that no accountant can verify the profit earned from input production, therefore the marginal cost. In short, effort is nonverifiable, hence non-contractible. The best the entrepreneur and worker can do is work without a contract and, following the worker's effort decision, rely on their bargaining powers to obtain shares of the profit from generic input production. ${ }^{11}$ The worker and the entrepreneur have bargaining weights $\lambda$ and $1-\lambda$, respectively. The worker chooses his level of effort $e$ (which is in monetary units) to maximize $\lambda \pi_{S}-e$, where $\pi_{S}$ is determined as in equation (1).

(iv.b) After they separate, the entrepreneur and worker first negotiate over whether the worker will continue to produce and supply the customized input. If they agree, the worker supplies the customized input to the entrepreneur at marginal cost $\bar{\mu}$ and receives a transfer. If they disagree, the worker does not produce the customized input and the entrepreneur must produce it himself at marginal cost $\overline{\bar{\mu}}>\bar{\mu} .{ }^{12}$ The entrepreneur then produces the final good and the worker produces the generic input, choosing effort to maximize $\pi_{S}-e$.

I label the values of the variables associated with the separation or spinout branch and associated with the together or integrated branch $O U T$ and $I N$, respectively. It is easy to show

\footnotetext{
${ }^{11}$ Here I am assuming that, after the worker's effort decision, the entrepreneur and worker can make a verifiable spot contract for actual delivery of output to the entrepreneur and payment to the worker. Signing such a contract in advance of the worker's effort decision, however, simply removes his incentive to exert effort.

${ }^{12}$ I continue to assume that the worker has no effort choice when he supplies the customized input, i.e., there is only one effort choice that permits coordination with production of the final good, so any other effort choice is equivalent to failure to produce the customized input (disagreement with the entrepreneur). When the entrepreneur takes over management of production of the customized input from the worker I assume he is less efficient because his time is less specialized to this task.
} 
that, as long as $\lambda<1$, the worker will choose greater effort when he separates from the entrepreneur, yielding greater profit net of effort from sales of the generic input:

$$
e^{O U T}>e^{I N} \text { and } \pi_{S}^{O U T}-e^{O U T}>\pi_{S}^{I N}-e^{I N} .
$$

Here we compute $\pi_{S}$ using equation (1).

At the end of the separation branch the entrepreneur earns

$$
\pi_{H}(z, \bar{\mu})-F-t^{O U T}(z)
$$

and the worker earns

$$
\pi_{S}^{O U T}-e^{O U T}-x+t^{O U T}(z)
$$

where

$$
t^{\text {OUT }}(\mathrm{z})=\lambda\left[\pi_{H}(z, \bar{\mu})-\pi_{H}(z, \overline{\bar{\mu}})\right]
$$

is the worker's share of the surplus from agreement. In contrast, at the end of the together branch the entrepreneur earns

$$
\pi_{H}(z, \bar{\mu})-F+(1-\lambda) \pi_{S}^{I N}
$$

and the worker earns

$$
\lambda \pi_{S}^{I N}-e^{I N}
$$

With efficient bargaining, therefore, separation will occur if and only if $x$ satisfies:

$$
x<\left(\pi_{S}^{O U T}-e^{O U T}\right)-\left(\pi_{S}^{I N}-e^{I N}\right) .
$$

At the point where the entrepreneur and worker decide whether to separate, if they agree each must receive his threat point (his earning at the end of the separation branch) plus his share of the surplus from agreement. It follows from equations (3), (4), and (8) that the entrepreneur receives

$$
\pi_{H}(z, \bar{\mu})-F-t^{O U T}(z)+(1-\lambda)\left[x+\left(\pi_{S}^{I N}-e^{I N}\right)-\left(\pi_{S}^{O U T}-e^{O U T}\right)\right]
$$

and the worker receives 


$$
\pi_{S}^{O U T}-e^{\text {OUT }}-x+t^{\text {OUT }}(z)+\lambda\left[x+\left(\pi_{S}^{I N}-e^{I N}\right)-\left(\pi_{S}^{\text {OUT }}-e^{\text {OUT }}\right)\right] .
$$

Comparing these earnings to the earnings at the end of the together branch given by equations (6) and (7), we see that the entrepreneur must make a transfer to the worker given by

$$
t^{I N}(x, z)=t(x)+t^{\text {OUT }}(z), \quad t(x) \equiv(1-\lambda)\left[\left(\pi_{S}^{\text {OUT }}-e^{\text {OUT }}\right)+e^{I N}-x\right] .
$$

This transfer must be nonnegative in order to satisfy the liquidity constraint of the worker. ${ }^{13}$ For this constraint to always be satisfied, it is sufficient that $t(\bar{x}) \geq 0$, or

$$
\bar{x} \leq\left(\pi_{S}^{O U T}-e^{O U T}\right)+e^{I N} .
$$

I am free to choose $\bar{x}$ small enough to ensure that this condition holds.

I can now compute the expected profits for an entrepreneur with talent $z$ who decides to enter production of high quality final goods:

$$
\Pi_{H}(z)=\pi_{H}(z, \bar{\mu})-F-t^{O U T}(z) Y(\hat{x})+\int_{\hat{x}}^{\bar{x}}\left[(1-\lambda) \pi_{S}^{I N}-t^{I N}(x, z)\right] d Y(x)
$$

where

$$
\hat{x}=\left(\pi_{S}^{O U T}-e^{O U T}\right)-\left(\pi_{S}^{I N}-e^{I N}\right)
$$

is the cost to the worker of starting his own business that makes the entrepreneur and worker exactly indifferent between separating and staying together, $\bar{x}$ satisfies equation $(10), t^{I N}(x, z)$ is given by equation (9), and $t^{O U T}(z)$ is given by equation (5). $\Pi_{H}(z)$ can be compared to the social benefit from entry of an entrepreneur with talent $z$ into production of high quality final goods:

$$
\widetilde{\Pi}_{H}(z)=\pi_{H}(z, \bar{\mu})-F+\int_{0}^{\hat{x}}\left(\pi_{S}^{O U T}-e^{O U T}-x\right) d Y(x)+\int_{\hat{x}}^{\bar{x}}\left(\pi_{S}^{I N}-e^{I N}\right) d Y(x) .
$$

There are three differences between $\widetilde{\Pi}_{H}(z)$ and $\Pi_{H}(z)$, all of which serve to make expected profits from entry into high quality final goods production less than the social benefit. First, the

\footnotetext{
${ }^{13}$ If the worker is forced to buy out the entrepreneur along the separation branch, the transfer will be negative. This means that it is not straightforward to solve for the impact of a policy that assigns property rights in the spinout to the entrepreneur, and indeed we expect such a policy to lead to inefficient bargaining outcomes given the liquidity constraint (though these outcomes could be more efficient from the point of view of society). See Rauch and Watson (forthcoming), who model bargaining between an entrepreneur, a worker, and a client where a liquidityconstrained worker attempts to start his own firm by serving a client formerly served by the entrepreneur's firm.
} 
third term in equation (13) gives the expected net profit from the spinout, which is completely lost to the entrepreneur. Second, the third term in equation (11) gives the expected transfer the spinout is able to extract from the entrepreneur to continue to supply the customized input, which is a wash from the point of view of society. Third, the difference between the last terms in equations (13) and (11) reflects the need for the entrepreneur to motivate the worker to stay with his firm and exert effort. ${ }^{14}$

I can now define the cutoff levels of managerial talent $\hat{z}$ and $\tilde{z}$ by $\Pi_{H}(\hat{z})=\pi_{L}$ and $\widetilde{\Pi}_{H}(\tilde{z})=\pi_{L}$, respectively. ${ }^{15}$ The value $\hat{z}$ is the level of managerial talent for which an old agent is just indifferent between entering production of high versus low quality goods, and $\tilde{z}$ is the level of managerial talent for which society is just indifferent between an old agent entering production of high versus low quality goods. Since $\Pi_{H}(z)<\widetilde{\Pi}_{H}(z)$, we have

Proposition 1. $\hat{z}>\tilde{z}$ : equilibrium entry into high quality final goods production is below the socially optimal level. That is, the equilibrium measure of the number of firms producing high quality final goods is $[1-G(\hat{z})] N$, which is less than the socially optimal number $[1-G(\tilde{z})] N$.

There are two interesting corollaries to Proposition 1. First, the equilibrium (measure of the) number of entrepreneurs in the industry being modeled is lower than the socially optimal number. This does not follow immediately from Proposition 1, because the number of entrepreneurs in final goods production is actually determined by the cutoff level of managerial talent for entry into low rather than high quality final goods production. However, more entry into low rather than high quality final goods production implies fewer subsidiaries producing intermediates, hence fewer spinouts and a lower total number of entrepreneurs. Second, the local content of exports will be below the socially optimal level, because entry of fewer high quality

\footnotetext{
${ }^{14}$ To see that this difference is positive, consider the difference $\left(\pi_{S}^{I N}-e^{I N}\right)-\left[(1-\lambda) \pi_{S}^{I N}-t^{I N}(x, z)\right]$. This reduces to $\left(\lambda \pi_{S}^{I N}-e^{I N}\right)+t^{I N}(x, z)$, where the expression in parentheses is just the earnings of the worker at the end of the together branch, given by equation (7).

${ }^{15}$ The existence of solutions for both of these equations can be ensured by assuming that $F$ is sufficiently large.
} 
final goods producers implies lower domestic production of inputs that exporters can purchase instead of imported inputs. This last point raises the intriguing possibility that reduced entry of high quality final goods producers has a "multiplier" effect: it may further discourage entry by raising costs because fewer domestically produced inputs are available.

\section{Spinouts with social networks and family firms}

In this section, I will analyze what happens when the worker is a member of the entrepreneur's social network and when he is a member of the entrepreneur's family. Since I will consider the entrepreneur's family to be a strict subset of his social network, I will analyze the family worker case second.

Collective sanctioning of deviant business behavior is typically analyzed in a repeated games framework (e.g., Greif 1993). To work within my static model, I instead emphasize immediate punishments such as social ostracism (e.g., exclusion from industry association banquets). In my model, the deviant action taken by the worker is refusing to supply the entrepreneur with the customized input after he has spun out (in contrast to the spinout decision itself, which is efficient and mutual). I denote the collective punishment imposed on the worker, measured in monetary units, by $\eta<\lambda\left[\pi_{H}(\hat{z}, \bar{\mu})-\pi_{H}(\hat{z}, \overline{\bar{\mu}})\right] /(1-\lambda)$. It is easily shown that the transfer from the entrepreneur to the worker $t^{O U T}(z)$ then falls to $\lambda\left[\pi_{H}(z, \bar{\mu})-\pi_{H}(z, \overline{\bar{\mu}})\right]-(1-\lambda) \eta$, where the restriction on $\eta$ ensures that this transfer is positive for any entrepreneur engaged in high quality production.

Proposition 2 follows immediately:

Proposition 2. When all entrepreneurs and workers are part of the same social network, then compared to its absence, entry into high quality final goods production is higher. 
It follows that the social network produces a higher volume of entrepreneurship, not because of a higher propensity to spin out (that remains the same), but because there are more vertically integrated firms from which to spin out. ${ }^{16}$ The social network will also increase the local content of exports, and its impact on entry may be amplified by the multiplier effect described after Proposition 1.

I now consider the case in which the skilled worker is not merely a member of the entrepreneur's social network but a member of his family. I define a family firm as a firm in which the entrepreneur is characterized by one-sided altruism towards the worker. I measure the strength of that altruism by $\theta$ and denote family firm variables by a subscript $f$. Since agents are risk-neutral, I can write the entrepreneur and worker utilities as

$$
U_{E f}=I_{E f}+\theta U_{W f}, U_{W f}=I_{W f}
$$

where $E$ denotes entrepreneur, $W$ denotes worker, $U$ is utility, and $I$ is income. I assume $0<\theta<1-\lambda$. It is as though the entrepreneur has an equity contract with the family worker that gives him a share $\theta$ of the worker's profits, yet this contract costs the worker nothing and is selfenforcing.

I next use the generalized Nash bargaining solution to find the division between the entrepreneur and the worker of the profit $\pi_{S}$ from generic input production at the end of the together branch. I assume that the bargaining weights, which are determined by parameters of the bargaining protocol, are unchanged. Using equation (14), I solve:

$$
\operatorname{Max}\left\{I_{E f}, I_{W f}\right\}\left(I_{E f}+\theta I_{W f}\right)^{1-\lambda}\left(I_{W f}\right)^{\lambda} \text { s.t. } I_{E f}+I_{W f}=\pi_{S}
$$

\footnotetext{
16 This conclusion must be qualified if the social network also reduces the costs to the workers of starting their own businesses, which is the impact of networks emphasized by Gompers et al. (2005) in the U.S. context. This implies a first-order stochastically dominated distribution of $x$, generating a higher propensity to spin out but a lower rate of entry into high quality final goods production, with an ambiguous net effect on the volume of entrepreneurship.
} 
where the disagreement points at the end of the together branch are zero. This yields $I_{W f}=[\lambda /(1-\theta)] \pi_{S}$ and $I_{E f}=[1-\lambda /(1-\theta)] \pi_{S}$. We see that, relative to a non-family worker, a family worker receives a larger share of the profit (but strictly less than one), and will therefore supply more effort along the together branch:

$$
e^{O U T}>e_{f}^{I N}>e^{I N} \text { and } \pi_{S}^{O U T}-e^{O U T}>\pi_{S f}^{I N}-e_{f}^{I N}>\pi_{S}^{I N}-e^{I N} .
$$

Working through the rest of the interaction between the entrepreneur and the (family) worker described in section 2, it is straightforward to show that equations (3) and (4) continue to hold, and equations (5) - (7) become

$$
\begin{gathered}
t_{f}^{O U T}(\mathrm{z})=[\lambda /(1-\theta)]\left[\pi_{H}(z, \bar{\mu})-\pi_{H}(z, \overline{\bar{\mu}})\right]-[1-\lambda /(1-\theta)] \eta \\
\pi_{H}(z, \bar{\mu})-F+[1-\lambda /(1-\theta)] \pi_{S f}^{I N} \text {, and } \\
{[\lambda /(1-\theta)] \pi_{S f}^{I N}-e_{f}^{I N} .}
\end{gathered}
$$

With efficient bargaining, separation now occurs if and only if $x$ satisfies:

$$
x<\left(\pi_{S}^{O U T}-e^{O U T}\right)-\left(\pi_{S f}^{I N}-e_{f}^{I N}\right) .
$$

Combing equation $(2 f)$ with equations $(8)$ and $(8 f)$ yields:

Proposition 3. The entrepreneur and family worker will stay together for a lower draw of $x$ than would the entrepreneur and non-family worker.

Intuitively, the sum of entrepreneur and worker income along the together branch is greater because the family worker supplies more effort, and the sum along the separation branch is the same, so the family worker is less likely to spin out.

I can now compute the total expected utility for an entrepreneur with talent $z$ who enters high quality final goods production and hires a family worker of ability equal to that of the best available workers: ${ }^{17}$

\footnotetext{
${ }^{17}$ The bargaining weight $1-\lambda$ appears in this equation instead of $1-\lambda /(1-\theta)$ because the entrepreneur's expected utility includes the $\theta$ times the expected utility (income) of the family worker; that is, $1-\lambda /(1-\theta)+$
} 


$$
\begin{aligned}
\Pi_{H f}(z)= & \pi_{H}(z, \bar{\mu})-F-(1-\theta) t_{f}^{O U T}(z)+\int_{0}^{\bar{x}} \theta\left(\pi_{S}^{O U T}-e^{O U T}-x\right) d Y(x) \\
& +\int_{\hat{x}_{f}}^{\bar{x}}(1-\lambda)\left[\left(\pi_{S f}^{I N}-e_{f}^{I N}\right)-\left(\pi_{S}^{O U T}-e^{O U T}-x\right)\right] d Y(x)
\end{aligned}
$$

where

$$
\hat{x}_{f}=\left(\pi_{S}^{O U T}-e^{O U T}\right)-\left(\pi_{S f}^{I N}-e_{f}^{I N}\right),
$$

$\bar{x}$ satisfies equation (10), and $t_{f}^{\text {OUT }}(z)$ is given by equation (5f). To compute the difference between this expected utility and the expected utility (profit) of the same entrepreneur when he hires a non-family worker within his social network, substitute equations (5) and (9) into equation (11) and equation (5f) into equation (11f) to obtain

$$
\begin{aligned}
& \Pi_{H f}(z)-\Pi_{H}(z)=\int_{0}^{\bar{x}} \theta\left[\left(\pi_{S}^{O U T}-e^{\text {OUT }}-x\right)-\eta\right] d Y(x) \\
& +\int_{\hat{x}_{f}}^{\hat{x}}(1-\lambda)\left[\left(\pi_{S f}^{I N}-e_{f}^{I N}\right)-\left(\pi_{S}^{O U T}-e^{O U T}-x\right)\right] d Y(x) \\
& \quad+\int_{\hat{x}}^{\bar{x}}(1-\lambda)\left[\left(\pi_{S f}^{I N}-e_{f}^{I N}\right)-\left(\pi_{S}^{I N}-e^{I N}\right)\right] d Y(x) .
\end{aligned}
$$

The first term is the extra utility the entrepreneur gets from having an altruistic "equity stake" in the spinout of the family worker. It is positive if the expected threat point of a worker when bargaining over spinout supply of the customized input is positive. The second and third terms reflect the additional profit earned by the entrepreneur because the family worker supplies more effort.

However, the total expected utility for an entrepreneur with talent $z$ who hires a family worker of ability equal to that of the best available workers still falls short of even the observed total expected profit generated by his entry into high quality final goods production. The latter is given by

$\theta \lambda /(1-\theta)=1-\lambda$. The upper bound for $\bar{x}$ in this equation given by equation (10) still ensures a non-negative transfer from the entrepreneur to the family worker because the family worker has, in effect, a greater bargaining weight than the non-family worker. 


$$
\widetilde{\Pi}_{H f}(z)=\pi_{H}(z, \bar{\mu})-F+\int_{0}^{\hat{x}_{f}}\left(\pi_{S}^{O U T}-e^{O U T}-x\right) d Y(x)+\int_{\hat{x}_{f}}^{\bar{x}}\left(\pi_{S f}^{I N}-e_{f}^{I N}\right) d Y(x) .
$$

The difference between this expected profit and the expected utility obtained by this entrepreneur given by equation $(11 f)$ equals

$$
\begin{gathered}
\widetilde{\Pi}_{H f}(z)-\Pi_{H f}(z)=(1-\theta) t_{f}^{O U T}(z)+\int_{0}^{\hat{x}_{f}}(1-\theta)\left(\pi_{S}^{O U T}-e^{O U T}-x\right) d Y(x) \\
+\int_{\hat{x}_{f}}^{\bar{x}}\left[\lambda\left(\pi_{S f}^{I N}-e_{f}^{I N}\right)+(1-\lambda-\theta)\left(\pi_{S}^{O U T}-e^{O U T}-x\right)\right] d Y(x)
\end{gathered}
$$

The first term equals the part of the net transfer from the entrepreneur to the worker in response to the latter's threat to withhold the customized input when he spins out that does not come back to the entrepreneur through family altruism. The second term reflects the fact that the entrepreneur does not value profits received by the family worker as highly as profits received by himself, and the third term reflects the need for the entrepreneur to share the profits from the input division with the worker even when the entrepreneur and worker stay together.

Equations (15) and (16) establish

Proposition 4. The cutoff level of talent for an entrepreneur to enter high quality final goods production is lower when he can hire a family worker of ability equal to that of the best available workers, but not as low as it would be if he could capture all of the observable profits generated by his entry. ${ }^{18}$

The availability of family workers augments the positive effect that the existence of the social network has on entry into high quality final goods production, but not enough to eliminate the problem of sub-optimal entry.

Finally, I consider the possibility that the best family worker available to the entrepreneur has ability lower than that of the best available non-family workers. It is then easy to show that the profitability of observed family firms can be lower as well as higher than the profitability of

\footnotetext{
${ }^{18}$ A sufficient condition for Proposition 4 to hold is that the worker's expected threat point when bargaining over spinout supply of the customized input is non-negative.
} 
non-family firms. Suppose that lower worker ability raises the marginal costs of production for both the customized and generic inputs, thereby lowering profits from both the final and intermediate goods divisions of the firm. Might the entrepreneur hire a family worker even if this effect more than offsets the positive effect on profits from greater worker effort? The answer is yes, because the entrepreneur still gets the term $\int_{0}^{\bar{x}} \theta\left[\left(\pi_{S}^{O U T}-e^{O U T}-x\right)-\eta\right] d Y(x)$ which he does not obtain when he hires a non-family worker. Ironically, it is the unobserved ability of the family firm to capture the profits from spinouts that can cause the observed profitability of a family firm to be lower than that of an otherwise comparable non-family firm. ${ }^{19}$

\section{Conclusions}

The key market failure discussed in this paper can be addressed directly by enforcing non-compete clauses in employment contracts and making loans to workers to buy out their contracts when spinouts are the efficient option. Yet it may not be realistic to implement this first-best theoretical solution in practice. Finance constraints may not be binding in more developed countries such as the United States (see, e.g., Hurst and Lusardi 2004 for evidence), but many studies (e.g., Wang 2012) attest to their continued relevance in developing countries. Enforcement of non-compete clauses in the presence of finance constraints risks over-correcting the problem and stifling spinoff entrepreneurship in general (Rauch and Watson forthcoming). Social networks and especially family firms may therefore be the second best solution available

\footnotetext{
${ }^{19}$ Clearly profits of the family firm can be lower along the together branch, which is the branch along which the econometrician typically observes the firm. If the econometrician observes the profits of business groups into which spinouts have been incorporated, the same argument demonstrates that the profits of family business groups may be higher or lower than those of non-family business groups until the death of the original entrepreneur, after which profits of family business groups must be (weakly) lower because the (weakly) lower ability of family workers will no longer be offset by their higher effort.
} 
for the problem of inadequate entry of high quality final goods producers due to the threat of employee spinouts.

Greater entry of vertically integrated firms with high-ability family members in charge of their input divisions may alleviate not only the market failures emphasized in this paper but also the "coordination failure" between suppliers of intermediates and producers of final goods emphasized by Rodrik (1995). Rodrik argued that, when international trade in inputs is costly, input producers may not enter if domestic final goods firms are not present to provide demand, but final goods firms may not enter if domestic input producers are not present to provide supply. This coordination failure prevents countries with potential comparative advantage from moving into production and export of higher quality, higher technology manufactured goods. Rodrik (1995) recognized the value of vertical business groups in overcoming this problem, and described preferential treatment given to these groups by the governments of South Korea and Taiwan. This paper contributes to understanding the market failures that motivated such policies, at least for the founding firms of the business groups, and also the concentration on certain families.

I have at several points in this paper implied that spinouts lead to the formation of business groups, ${ }^{20}$ particularly family business groups. However, a key feature of business groups is internal capital markets and especially equity holdings of the lead firm in the subordinate firms (Khanna and Yafeh 2007). Given the intimate knowledge the parent firm has of the spinout in my model, it would be natural for the spinout to turn to the parent rather than an external bank to meet its financing needs. From there it seems a small step to equity holdings by the parent in the spinout, which in family business groups could replace the ties of affect that

\footnotetext{
${ }^{20}$ Gerlach and Lincoln (2000), for example, show how the Japanese keiretsu expand through continuous spinout of satellite firms.
} 
vanish with the death of the founder. ${ }^{21}$ Future research should include formal modeling of this process and empirical investigation of its frequency.

\footnotetext{
${ }^{21}$ When restrictive employment covenants such as non-competes are enforced (or the spinout violates patent laws that are enforced), the parent firm may accept equity in the spinout as compensation. This mode of formation of business groups is therefore not restricted to a developing country context. For evidence on the importance of internal capital markets for European business groups, see Belenzon, Berkovitz and Rios (forthcoming).
} 


\section{References}

Alesina, Alberto and La Ferrara, Eliana. 2005. "Ethnic Diversity and Economic Performance." Journal of Economic Literature 43(3): 762-800.

Anderson, Ronald C. and Reeb, David M. 2003. "Founding-Family Ownership and Firm Performance: Evidence from the S\&P 500.” Journal of Finance 63: 1301-1328.

Atalay, Enghin; Hortaçsu, Ali; and Syverson, Chad. 2013. "Vertical Integration and Input Flows." University of Chicago Working Paper (March).

Belenzon, Sharon; Berkovitz, Tomer; and Rios, Luis. Forthcoming. "Capital Markets and Firm Organization: How Financial Development Shapes European Corporate Groups.” Management Science.

Bertrand, Marianne; Johnson, Simon; Samphantharak, Krislert; and Schoar, Antoinette. 2008. "Mixing Family With Business: A Study of Thai Business Groups and the Families Behind Them." Journal of Financial Economics 88(3): 466-498.

Chua, Amy L. 1998. "Markets, Democracy, and Ethnicity: Toward a New Paradigm for Law and Development." Yale Law Journal 108(1): 1-107.

Chung, Wai-keung and Hamilton, Gary G. 2001. "Social Logic as Business Logic: Guanxi, Trustworthiness, and the Embeddedness of Chinese Business Practices." In Rules and Networks: The Legal Culture of Global Business Transactions, edited by Richard P. Appelbaum, William L. F. Felstiner, and Volkmar Gessner. Oxford: Hart Publishing, 325-346.

Claessens, Stijn; Djankov, Simeon; Fan, Joseph P. H.; and Lang, Larry H. P. 2002. "Disentangling the Incentive and Entrenchment Effects of Large Shareholders." Journal of Finance 62: 2741-2771.

Costinot, Arnaud; Oldenski, Lindsay; and Rauch, James E. 2011. "Adaptation and the Boundary of Multinational Firms." Review of Economics and Statistics 93: 298-308.

Cronqvist, Henrik and Nilsson, Mattias. 2003. "Agency Costs of Controlling Minority Shareholders." Journal of Financial and Quantitative Analysis 38: 695-719.

Forbes, Silke and Lederman, Mara. 2009. "Adaptation and Vertical Integration in the Airline Industry.” American Economic Review 99: 1831-1849.

Garmaise, Mark J. 2011. "Ties That Truly Bind: Noncompetition Agreements, Executive Compensation, and Firm Investment." Journal of Law, Economics, and Organization 27: 376-425. 
Gerlach, Michael L. and Lincoln, James R. 2000. "Economic Organization and Innovation in Japan: Networks, Spin-offs, and the Creation of Enterprise." In George Von Krogh, Ikujirō Nonaka, and Toshihiro Nishiguchi, eds., Knowledge Creation: A Source of Value (New York: Palgrave): 151-196.

Gibbons, Robert. 2005. "Four formal(izable) theories of the firm?" Journal of Economic Behavior and Organization 58(2): 200-245.

Gilson, Ronald J. 1999. “The Legal Infrastructure of High Technology Industrial Districts: Silicon Valley, Route 128, and Covenants Not to Compete." New York University Law Review 74: 575-628.

Gompers, Paul; Lerner, Josh; and Scharfstein, David. 2005. "Entrepreneurial Spawning: Public Corporations and the Genesis of New Ventures, 1986-1999." Journal of Finance 60(2): 577-614.

Greif, Avner. 1993. "Contract Enforceability and Economic Institutions in Early Trade: The Maghribi Traders' Coalition.” American Economic Review 83(3): 525-548.

Grossman, Gene and Helpman, Elhanan. 1991. "Endogenous Product Cycles." Economic Journal 101 (September): 1214-1229.

Hurst, Erik, and Lusardi, Annamaria. 2004. "Liquidity Constraints, Household Wealth and Entrepreneurship." Journal of Political Economy 112: 319-347.

Khanna, Tarun and Palepu, Krishna. 2000. "Is Group Affiliation Profitable in Emerging Markets? An Analysis of Diversified Indian Business Groups." Journal of Finance 55: 867-891.

Khanna, Tarun and Yafeh, Yishay. 2007. "Business Groups in Emerging Markets: Paragons or Parasites?" Journal of Economic Literature 45(2): 331-372.

Lucas, Robert E., Jr. 1978. “On the Size Distribution of Business Firms.” Bell Journal of Economics 9(2): 508-523.

Malsberger, Brian M. 2006. Covenants Not to Compete: A State-by-State Survey. Washington, D.C.: Bureau of National Affairs.

Melitz, Marc J. 2003. “The Impact of Trade on Intra-industry Reallocations and Aggregate Industry Productivity." Econometrica 71: 1695-1725.

Muendler, Marc; Rauch, James E., and Tocoian, Oana. 2012. "Employee Spinoffs and Other Entrants: Stylized Facts from Brazil." International Journal of Industrial Organization 30: 447-458. 
Rauch, James E. 2010. “Development Through Synergistic Reforms," Journal of Development Economics 93: 153-161

Rauch, James E. and Watson, Joel. Forthcoming. “Client-Based Entrepreneurship.” Journal of Law, Economics, and Organization.

Rodrik, Dani. 1995. "Getting Interventions Right: How South Korea and Taiwan Grew Rich." Economic Policy 20 (April): 53-97.

Shieh, Gwo-shyong. 1992. "Boss” Island: The Subcontracting Network and Microentrepreneurship in Taiwan's Development. New York: Peter Lang.

Tong, Chee Kiong. 2006. "Rethinking Chinese Business Networks: Trust and Distrust in Chinese Business." Journal of Asian Business 22(3): 145-168.

Tybout, James R. 2000. "Manufacturing Firms in Developing Countries: How Well Do They Do, and Why?" Journal of Economic Literature 38 (March): 11-44.

Wang, Shing-Yi. 2012. "Credit Constraints, Job Mobility, and Entrepreneurship: Evidence from a Property Reform in China." Review of Economics and Statistics 94(2): 532-551. 